\title{
Hydrochemical Characteristics of the Groundwater AQ1 of the Region from Pointe-Noire to Congo Brazzaville
}

\author{
D. Nkounkou Tomodiatounga, B. Mabiala*, G. Moukandi Nkaya \\ Higher National Polytechnic School, Marien Ngouabi University, Brazzaville, Congo \\ Email: ^bernamab@yahoo.com
}

How to cite this paper: Nkounkou Tomodiatounga, D., Mabiala, B. and Moukandi Nkaya, G. (2016) Hydrochemical Characteristics of the Groundwater AQ1 of the Region from Pointe-Noire to Congo Brazzaville. Journal of Geoscience and Environment Protection, 4, 95-109.

http://dx.doi.org/10.4236/gep.2016.49008

Received: August 12, 2016

Accepted: September 25, 2016

Published: September 28, 2016

Copyright $\odot 2016$ by authors and Scientific Research Publishing Inc. This work is licensed under the Creative Commons Attribution International License (CC BY 4.0).

http://creativecommons.org/licenses/by/4.0/ (c) (i) Open Access

\begin{abstract}
The study is interested in chemical quality of water of the one of the five aquifers, unconfined water AQ1, (other free groundwaters AQ2, AQ3, AQ4 and AQ5 being captive) in the area of Pointe-Noire. A series of physicochemical analysis was carried out on the samples of water of the zone. The results of these analyses were treated starting from a chemical-hydro method which uses the diagrams of Piper, Stabler, Schoeller Berkaloff, Stiff, Wilcox and the statistical methods classic. These chemicalhydro results made it possible to highlight the prevalence of sodic and potassic facies chlorinated in groundwaters of the unconfined water of the area of Pointe-Noire. In this area, the groundwaters of the unconfined water gather in three principal-hydro facies: sodic and potassic chlorinated waters are the most important (66.7\%) in the studied water; calcic and magnesian bicarbonated water (16.65\%) and bicarbonated sodic and potassic ones (16.65\%). This study reveals that the groundwaters of the area of Pointe-Noire undergo an intrusion saltworks. As a whole, these groundwaters require in certain cases, a specific treatment before consumption.
\end{abstract}

\section{Keywords}

Hydrochemistry, Unconfined Water AQ1, Pointe-Noire

\section{Introduction}

The groundwater is of a major importance in most areas of the world. However, this resource which was formerly of good quality, is presently threatened by various punctual and diffuse sources of contamination. The groundwaters constitute the main source of supply of the inhabitants of the area of Pointe-Noire. This area belongs to the 
coastal sedimentary basin, which extends on a surface from approximately $6000 \mathrm{~km}^{2}$ and is located in the south west part of the Congo. This coastal sedimentary basin presents a system hydrogeological to aquifer multi-layer ranging between 10 and $400 \mathrm{~m}$ from depth to Pointe-Noire and 70 and $150 \mathrm{~m}$ with the Indian Point. These aquifers are separated by intercalations from very composite materials (marly limestone, consolidated sandstones, clay...) of the reddish argilo sandy series of the greso-dolomitic and do not present a regular profile; the tender sands and sandstones are sandwiched between these layers. Water which it contains satisfies the water requirements drinkable, in industry and sylviculture. This water which constitutes an element impossible to circumvent for the economic development of the area is threatened of contamination. In spite of the importance of the economic and medical interests concerned, the operation of the multi-layer aquifer is still very badly known and the consequences of exponential and uncontrolled exploitation since the massive appearance of major drillings and traditional wells are not evaluated [1]. In the area of Pointe-Noire the only aquifers most exploited are AQ-1 and AQ2 (Figure 1). An investigation and observations on the ground show that aquifer AQ-1 is exploited by the population to supply itself with water via going wells of surface of depth from 0.50 to $10 \mathrm{~m}$ at the end of the dry season with an important seasonal variation going from 3 to $5 \mathrm{~m}$. The exploitation of this aquifer being made in an artisanal way does not have precise data as for its evolution.

In spite of the identified threat and the economic, social and medical challenges that represent the aquiferous system of the coastal sedimentary basin of Pointe-Noire, the study and the management of this resource are not the objects of any program. Current knowledge relating only to the urban area of Pointe- Noire (and not the whole of the basin), comes essentially, from the research tasks of water [2] [3], academics [1] [4] [5] which came to supplement those of the tankers. Since the end of 1980, the report of an intrusion of important salted bevel in the coastal accesses concentrated all the attentions of the public managers and the territorial collectivities.

It is thus advisable to know and follow the quality of this resource. The chemical composition of a water resulting from the natural environment is very variable. It depends on the geological nature of the ground from where it comes and also on the reactive substances which it could have met during the flow.

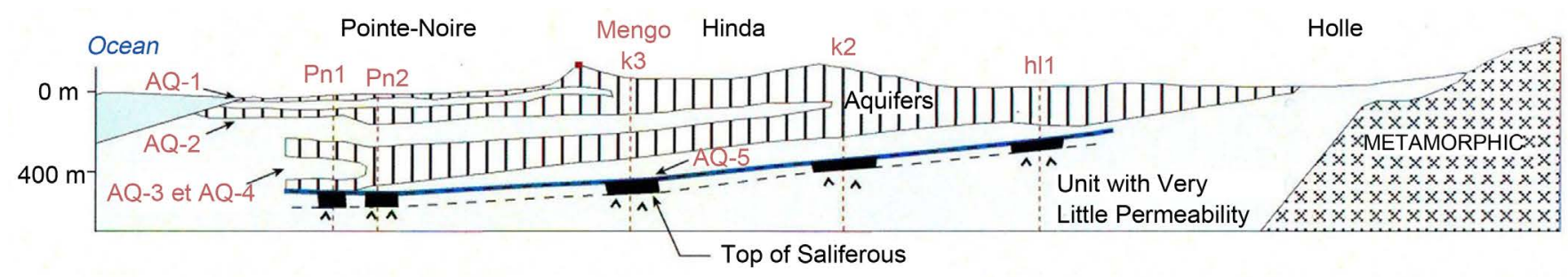

\begin{tabular}{|c|c|c|}
\hline$\square П \square$ Confirmed Aquifer & - Potential Aquifer & - - Saliferous Serie \\
\hline
\end{tabular}

$0 \quad 24 \mathrm{~km}$

Figure 1. Hydrogeological cutting of the region of Pointe-Noire. 
Underground water quality can be faded when external substances make contact with the aquifer. Such is the case of the even toxic undesirable substances which make groundwater unsuitable and toxic for various uses in particular for the use as drink water. The intensive use of the natural resources and the increase of human activities generate serious problems on the quality of the groundwaters [6] [7].

The purpose of this hydrochemical study of the water of the hydrogeological AQ1 of the complex of the urban area of Pointe-Black is to identify the chemical facies of water, their degree of potability, as well as their aptitude for the overexploitation of this aquifer involving a probability of intrusion saltworks. It also makes it possible to follow the space-time evolution of the physicochemical parameters and to consider their mineral origin. Hydrogeological and physicochemical studies of groundwaters will be integrated and employed to determine the influence of these factors and the mechanisms controlling the chemistry of groundwaters in the area.

\section{Materials and Methods}

The physicochemical analyses were carried out on water of private wells of public use collecting the water table of the hydrogeological complex, including an aquiferous system composed of several aquifers superimposed with a hydraulic continuity, pertaining to the coastal sedimentary basin. This basin consists of a vast depression filled by a complex of plio-quaternary, tertiary and secondary deposits containing five aquiferous horizons or aquifers.

The samplings are carried out and conditioned in bottles especially prepared for this purpose. The samplings are carried out using an especially designed sampler. The device of sampling is carefully washed with the distilled water before each taking away. The near total of the water supply points of the aquifers is intended for the drinking water supply. To be used, water must meet certain standards which vary according to the type of use. The water samples intended for the chemical analyses were taken in eighteen (18) wells of the urban area of Pointe-Noire (Figure 2). For each test, physical parameters namely the $\mathrm{pH}$, the temperature, and conductivity are measured in situ using a pH-meter and of a conductimeter of brand WTW 330.

The water samples were immediately stored with $4^{\circ} \mathrm{C}$ in a refrigerator containing the ice, the analysis was quickly carried out less $24 \mathrm{H} 00$ after the taking away. The major elements Calcium $\left(\mathrm{Ca}^{2+}\right)$, Magnesium $\left(\mathrm{Mg}^{2+}\right)$, Sodium $\left(\mathrm{Na}^{+}\right)$, Potassium $\left(\mathrm{K}^{+}\right)$, chloride $(\mathrm{Cl})$, bicarbonate $\left(\mathrm{HCO}_{3}^{-}\right)$, sulphate $\left(\mathrm{SO}_{4}^{2-}\right)$ and hardness are analyzed in the laboratories of Civil engineering of the Higher National Polytechnic School (ENSP), the Research institute in Exact sciences and Natural (IRSEN) and of the National company of Water supply (SNDE). These analyses were carried out using a spectrophotometer by using the standardized classical methods.

The potability of water is defined by biological chemicaland physical parameters, but especially according to its use. A comparison of the contents of physical and chemical elements of water of various drillings to the standards of the World Health Organization was carried out according to [1]. The hydrochimical analysis was then carried out 


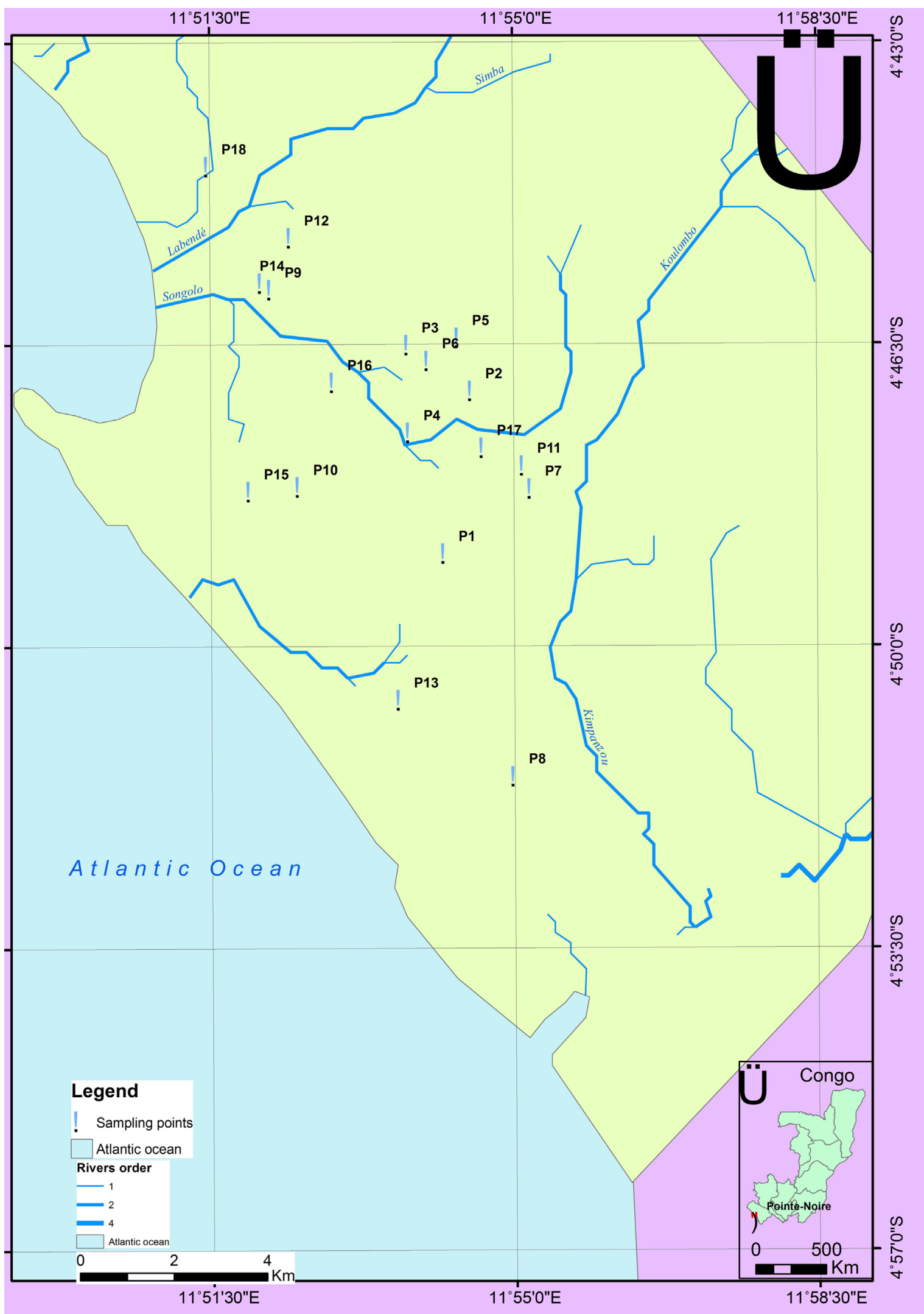

Figure 2. Localization of the water samples taken for chemical analyses. 
using the diagram of Piper in particular to characterize the geochemical facies of water of the AQ1 of the urban area of Pointe-Noire. This diagram is very frequently used and gives very good performances [1] [8]-[15]. The treatment was possible thanks to the software DIAGRAMS.

The second approach is based on the use of the various classical statistical analyses (average, quantile, median, standard, and the variance). The whole of the data collected on groundwaters of the area was the object of this statistical study. The statistical analysis has been carried out on 18 samples and 13 variables (electric conductivity (EC), the $\mathrm{pH}$, the temperature $\left(\mathrm{T}^{\circ} \mathrm{C}\right)$, hardness, TDS, $\mathrm{Ca}^{2+}, \mathrm{Mg}^{2+}, \mathrm{Na}^{+}, \mathrm{K}^{+}, \mathrm{Cl}, \mathrm{HCO}_{3}^{-}, \mathrm{NO}_{3}^{-}$and $\mathrm{SO}_{4}^{2-}$ ) using the software RStudio. These various analysis make it possible to characterize the physicochemical aspects of the water of the water table of the AQ1 of the aquiferous system of the area of Pointe-Noire.

The spatialization of the points of measurements was represented witch the help of the software Arc-Gis 8.2.

To assess the quality of the chemical analyses, the error of analysis on each water sample was evaluated starting from the formula (1) of the ionic balance:

$$
e=\frac{\sum r_{\text {anions }}-\sum r_{\text {cations }}}{\sum r_{\text {anions }}+\sum r_{\text {cations }}} \times 100= \pm 5 \%
$$

in which $r$ represent the ionic concentration (meq/l).

\section{Results and Discussion}

For better understanding and better quantifying the variations of each studied parameter, only one representation of the data was used. This representation is based on the calculation of some statistical parameters, presenting the maximum, average, minimal values median, quantiles and the variances (Table 1 and Table 2). To facilitate the comparison and to better interpret the got results, we have in the same tables, the various maximum standards of potability of the water intended for human consumption according to the World Health Organization (WHO).

These synthesized analysis in various Table 1 and Table 2, show that the temperature of water of the $\mathrm{AQ} 1$ of the area of Pointe-Noire varies between $25.4^{\circ} \mathrm{C}$ and $29.9^{\circ} \mathrm{C}$, with an average of $27.9^{\circ} \mathrm{C} \pm 1.0^{\circ} \mathrm{C}$. With regard to the $\mathrm{pH}$ of water of various points of measurement, it varies between 4.1 and 7.1 unities $\mathrm{pH}$, for an average of $6.0 \pm 0.6$. Electric conductivity varies between 19 and $937.1 \mu \mathrm{S} \cdot \mathrm{cm}^{-1}$, with a median value of $269.5 \pm$ 243.1 $\mu \mathrm{S} \cdot \mathrm{cm}^{-1}$. Water with strong conductivity are those of the well of Mpaka (936 $\mu \mathrm{S} \cdot \mathrm{cm}^{-1}$ ), the well of Mbota (551.9 and $542.0 \mu \mathrm{S} \cdot \mathrm{cm}^{-1}$ ), of the well of Tchiniambi (483.5 $\left.\mu \mathrm{S} \cdot \mathrm{cm}^{-1}\right)$ and of the well of Voungou $\left(436.7 \mu \mathrm{S} \cdot \mathrm{cm}^{-1}\right)$.

The hardness of groundwaters of the zone of study varies between $0.0^{\circ} \mathrm{F}$ and $11.0^{\circ} \mathrm{F}$, with an average of $3.2^{\circ} \mathrm{F}$. The water hardness is an indicator of the limestone level in water: it corresponds to its calcium content and magnesium. The more it contains some, the more it is "hard". That reveals that water is in extreme cases soft and fairly hard as a whole. The water described as very hard is water of the well of Mpaka $\left(11.0^{\circ} \mathrm{F}\right)$, of the well of Voungou $\left(7^{\circ} \mathrm{F}\right)$ and of the wells of Mbota $\left(5.0^{\circ} \mathrm{F}\right)$. According to the guide 
Table 1. Physic composition chemical average waters of the groundwater of the AQ1 of Pointe-Noire.

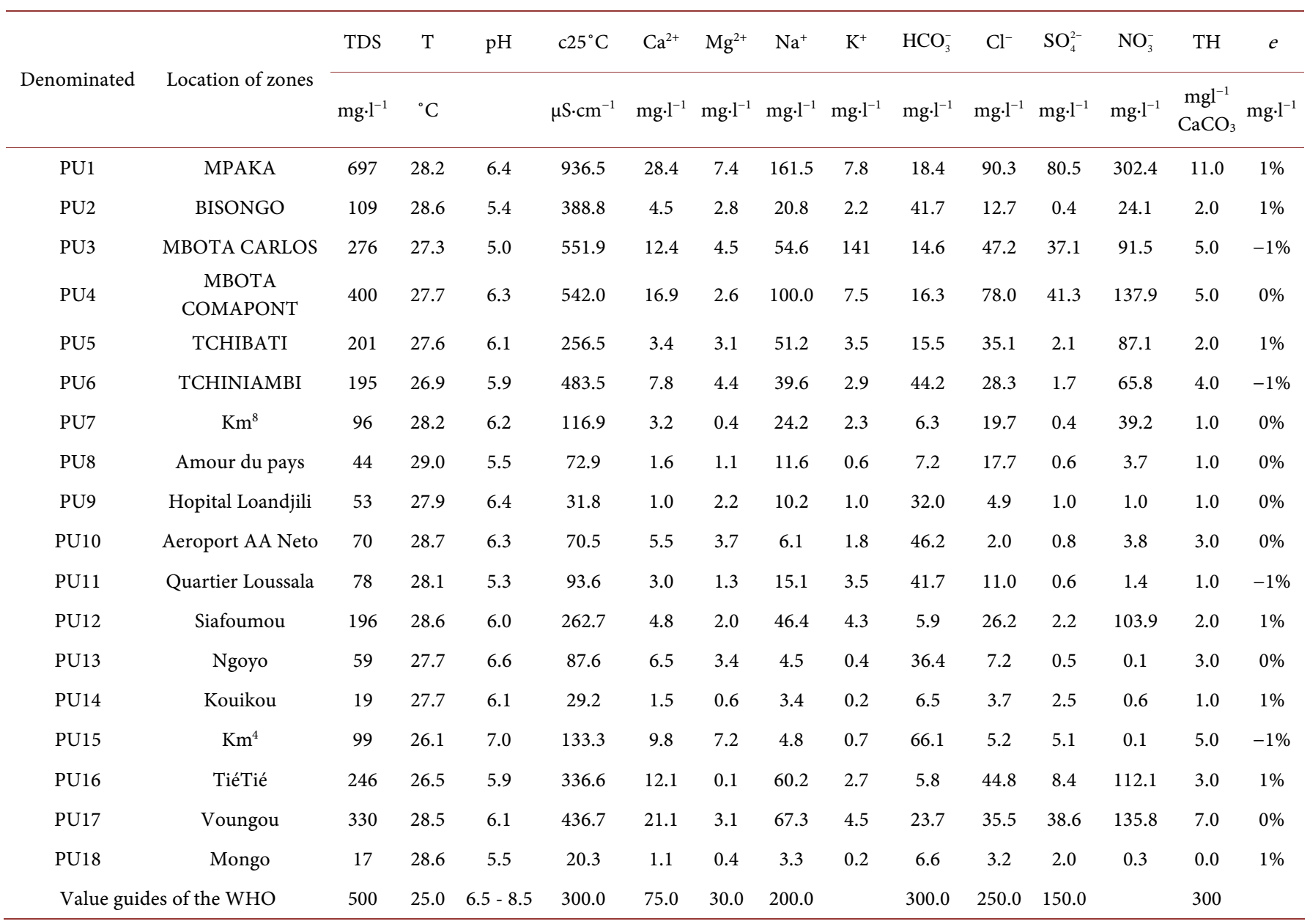

Table 2. Statistical analysis of the physic-chemical parameters.

\begin{tabular}{|c|c|c|c|c|c|c|c|c|}
\hline Name & Min & $\mathrm{q} 25$ & Median & q75 & $\operatorname{Max}$ & Mean & Sd & Var \\
\hline T_C & 25.4 & 27.4 & 28.0 & 28.6 & 29.9 & 27.9 & 1.0 & 1.0 \\
\hline $\mathrm{pH}$ & 4.1 & 5.6 & 6.1 & 64 & 7.1 & 6.0 & 0.6 & 0.3 \\
\hline $\mathrm{CE}$ & 19.0 & 74.3 & 135.7 & 438.0 & 937.1 & 269.5 & 243.1 & $59,090.8$ \\
\hline $\mathrm{Mg}$ & 0.1 & 0.9 & 2.8 & 3.5 & 8.6 & 2.8 & 2.1 & 4.5 \\
\hline $\mathrm{Na}$ & 2.4 & 5.5 & 21.7 & 54.9 & 161.9 & 38.0 & 40.3 & 1626.5 \\
\hline K & 0.1 & 0.7 & 2.6 & 4.3 & 16.4 & 3.3 & 3.5 & 11.9 \\
\hline $\mathrm{HCO}_{3}$ & 2.0 & 6.1 & 18.4 & 43.2 & 67.2 & 24.2 & 18.7 & 349.7 \\
\hline $\mathrm{TH}$ & 0.0 & 1.0 & 3.0 & 5.0 & 11.0 & 3.2 & 2.5 & 6.1 \\
\hline
\end{tabular}


of WHO, drinking of calcareous water or hard is not contra-indicated. Calcareous water takes part in the daily calcium contribution which the body needs (solidification of the bones, operation of the muscles, transmission of the nerve impulse, process of coagulation of blood). Water of the wells is characterized by the presence of the dissolved total solids which varies between 12 and $700 \mathrm{mg} / \mathrm{l}$. Water is rich in sodium, with contents which vary between 2.4 and $161.9 \mathrm{mg} / \mathrm{l}$, for an average of $38.8 \pm 40.3 \mathrm{mg} / \mathrm{l}$. The strongest value was obtained on the level of water of well of Mpaka (161.5 mg/l). The presence of sodium in water can be of anthropic origin or natural origin in the ground. Sodium can present dangers of encephalopathy for people to the chronic renal insufficiencies. The value of the guide of W.H.O of Total Sodium in the drink water is of 200 $\mathrm{mg} / \mathrm{l}$.

Water of the groundwater of the zone of study is rich in $\mathrm{Ca}^{2+}, \mathrm{K}^{+}$and $\mathrm{Mg}^{2+}$ with a spatial variability which differs from a point of measurement with another, for respective averages of $8.0 \pm 7.5 ; 3.3 \pm 3.5$ and $2.8 \pm 2.1 \mathrm{mg} / \mathrm{l}$. The ions sulphates $\left(\mathrm{SO}_{4}^{2-}\right)$ with concentrations higher to the value guides in the drink water can cause diarrhoeas in the human being [16]. The analysis of our data shows that the content of sulphate can be considered acceptable. The contamination by nitrates can be regarded as unacceptable with respect to the standard $50 \mathrm{mg} / \mathrm{l}$ for water of the wells of Mpaka, Mbota, Tchiniambi, Tchibati, Siafoumou, Tié-Tié, and Voungou (respectively: 302.4, 91.5, 65.8, 87.1, 103.9, 112.1 and $135.8 \mathrm{mg} / \mathrm{l})$.

The presence of nitrates testifies to a recent contamination resulting from the infiltration of waste waters and to a beginning of deficit of the environment in oxygen [17] [18]. The analyses of the water sampled in the area of Pointe-Noire show the values of the ions chlorides which vary between 1.9 and $90.9 \mathrm{mg} / \mathrm{l}$, for an average the $26.3 \pm 25.5$ mg/l. Water of the wells of Mpaka, Mbota, Tchiniambi, Tchibati, Siafoumou, Tié-Tié, and Voungou present a rate of high chloride concentration. Chlorine is not dangerous for the man, but chlorination makes it possible to obtain an exempted water of virus starting from a water polluted by fecal organism when its concentration is maintained to the standards. The bicarbonate values in the zone of study are variable with a moyenne $24.2 \pm 18.7 \mathrm{mg} / \mathrm{l}$. Indeed, water being saturated or supersaturated with respect to calcite, a reduction in $\mathrm{pH}$ involves a bicarbonate increase.

Chemical facies of water of the free groundwater: The chemical data in major elements are represented in the diagram of Piper (Figure 3) which allows a representation of the anions and cations on two specific triangles whose sides express the relative contents (\%) of each major ion compared to the total of these ions, expressed meq/l (cations: triangle of left, anions: triangle of right-hand side). The position of a water analysis in these two triangles makes it possible to specify which are the dominant anions and cations. The position of the analysis in the rhombus makes it possible to specify the total chemical facies [19]. It is important to stress that this diagram does not represent the total mineralization of a water, but only the distribution of the dissolved ions.

With each well a label of different colour and form was allotted. The diagram of Piper of the zone of study shows us the presence of 3 chemical facies including 12 samples having the facies chlorinated sodic and potassic either $67 \%$ of the total of the samples, 3 


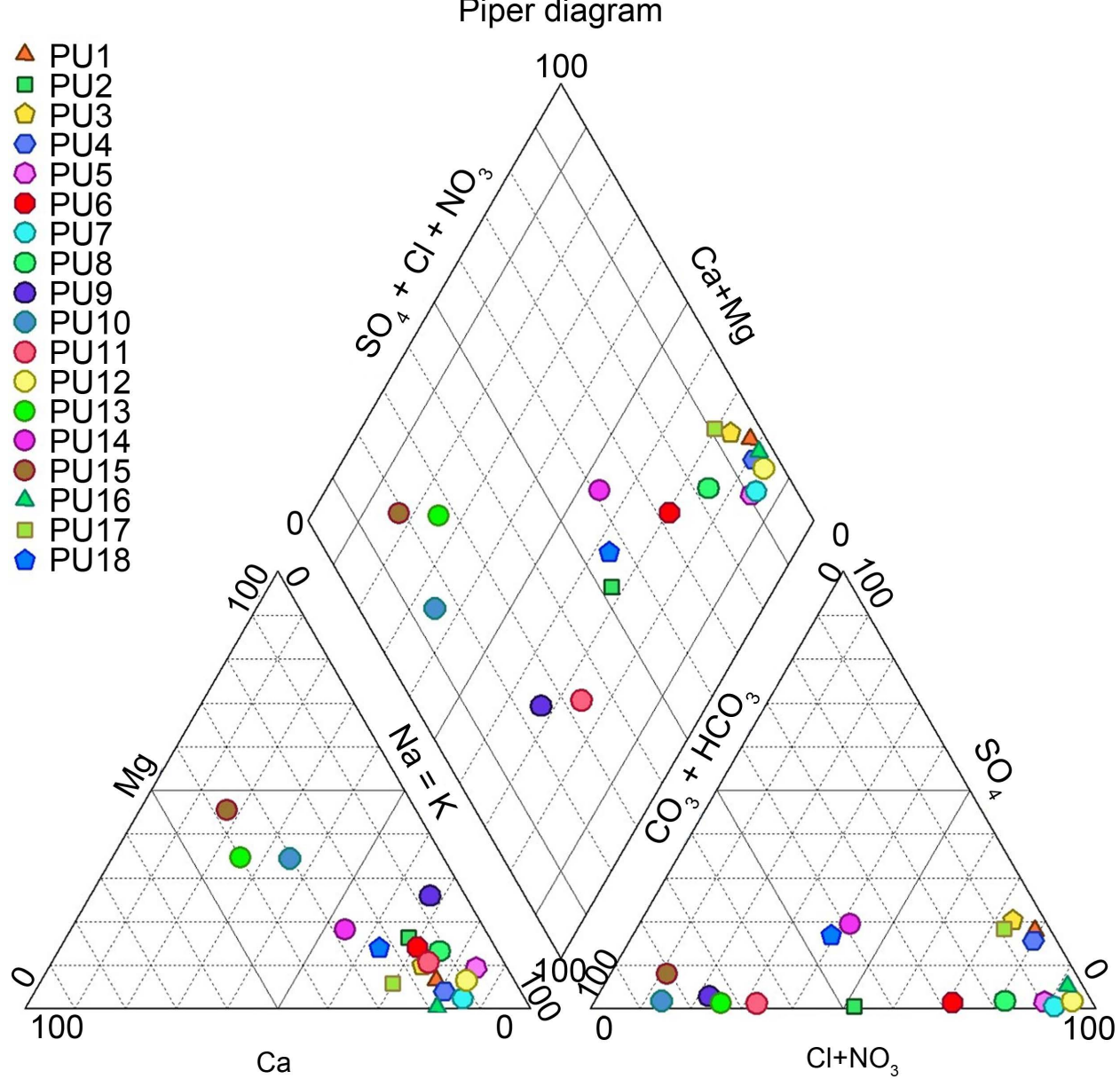

Figure 3. Classification of the ions from the mean annual Piper Diagram.

samples having the calcic and magnesian bicarbonated facies or $16.5 \%$ of the total and 3 samples present the sodic and potassic bicarbonated facies or $16.5 \%$ of the total (Figure 3). In the area of Pointe-Noire, water of the groundwater, is thus characterized by a prevalence of the ions chlorides on the ions bicarbonates and sulphates. Sodium constitutes the most important cation, then comes then $\mathrm{Ca}^{2+}$. Only wells PU8, PU3 and PU5 do not present dominant cations (Figure 4). From the diagram of Schöeller Berkaloff (Figure 5), we represented each analysis by a broken line, characteristic profile of the concentration of each major ion in solution in water, the six logarithmic scales at equal distance from/to each other, being shifted in order to align the unit values of the milliequivalents of various anions and cations. These profiles highlight the relationship of water between themselves, which show the presence of the three sodic and potassic chlorinated facies (in large the majority of the wells), bicarbonated sodic and potassic then the calcic and magnesian facies bicarbonated for water of the free groundwater of the area of Pointe-Noire.

This prevalence of the sodic and potassic facies chlorinated is shown through the diagram of Stiff (Figure 6). By analyzing the diagram of Stiff, onenotices the predominance of the cations $\mathrm{Na}^{+}$, and $\mathrm{K}^{+}$in the majority of the wells and of the anions $\mathrm{SO}_{4}^{2-}$ 
Stabler
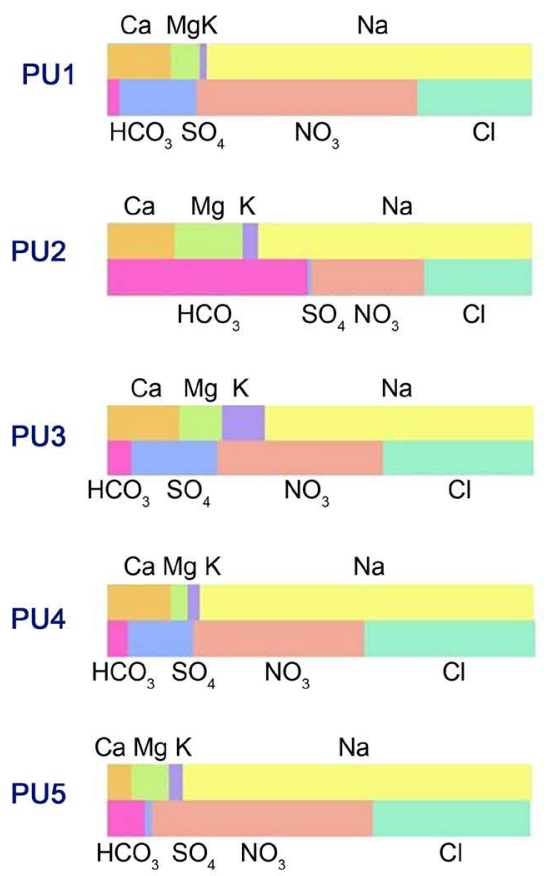

PU6
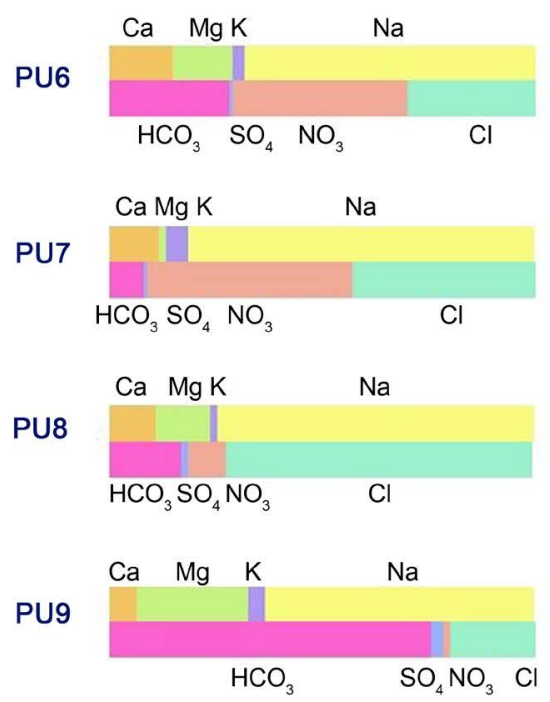

Unconfined AQ1

PU10

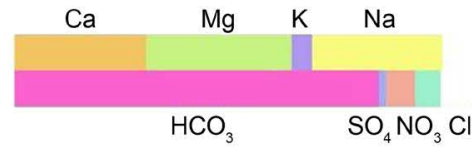

PU11
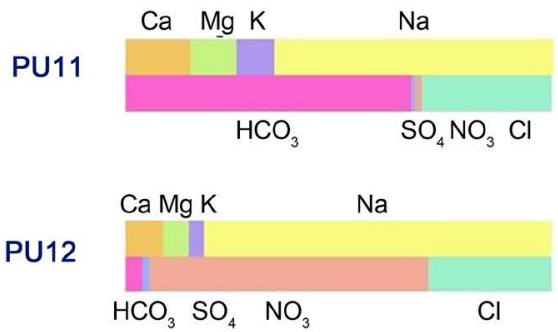

PU13

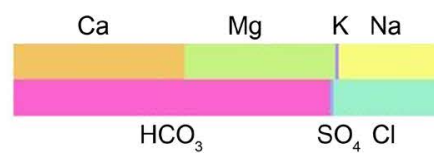

PU14

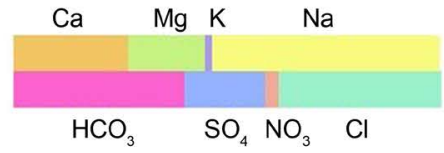

PU15

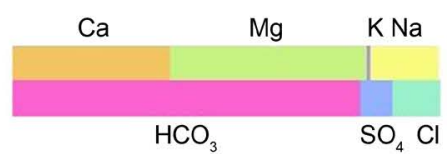

PU16

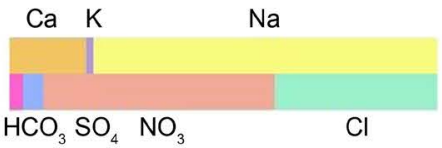

PU17

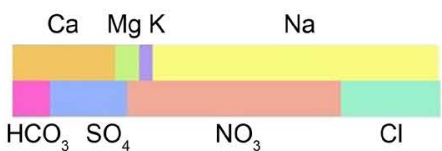

PU18

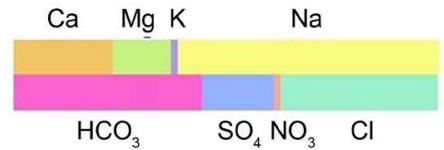

Figure 4. Classification of the ions from the Stabler Diagram.

and $\mathrm{NO}_{3}^{-}$, this one is due to the intrusion salt works and/or the immediate anthropic pollution of the wells in unconfined water AQ1.

The diagram of Wilcox (Figure 7) shows that the majority of the well collecting the unconfined water of the area of Pointe-Noire present an excellent water. Some wells such as: PU1, PU2, PU3, PU4, PU5 and PU16 present a more or less acceptable water. The calculation of relationship between chemical elements makes it possible to highlight the mixture of water of different origins. Several studies ([1] [20]-[23]) give examples of use of reports to identify the origin of the salinisation of water such as $\mathrm{Cl}^{-} / \mathrm{Br}$, 
Unconfined AQ1

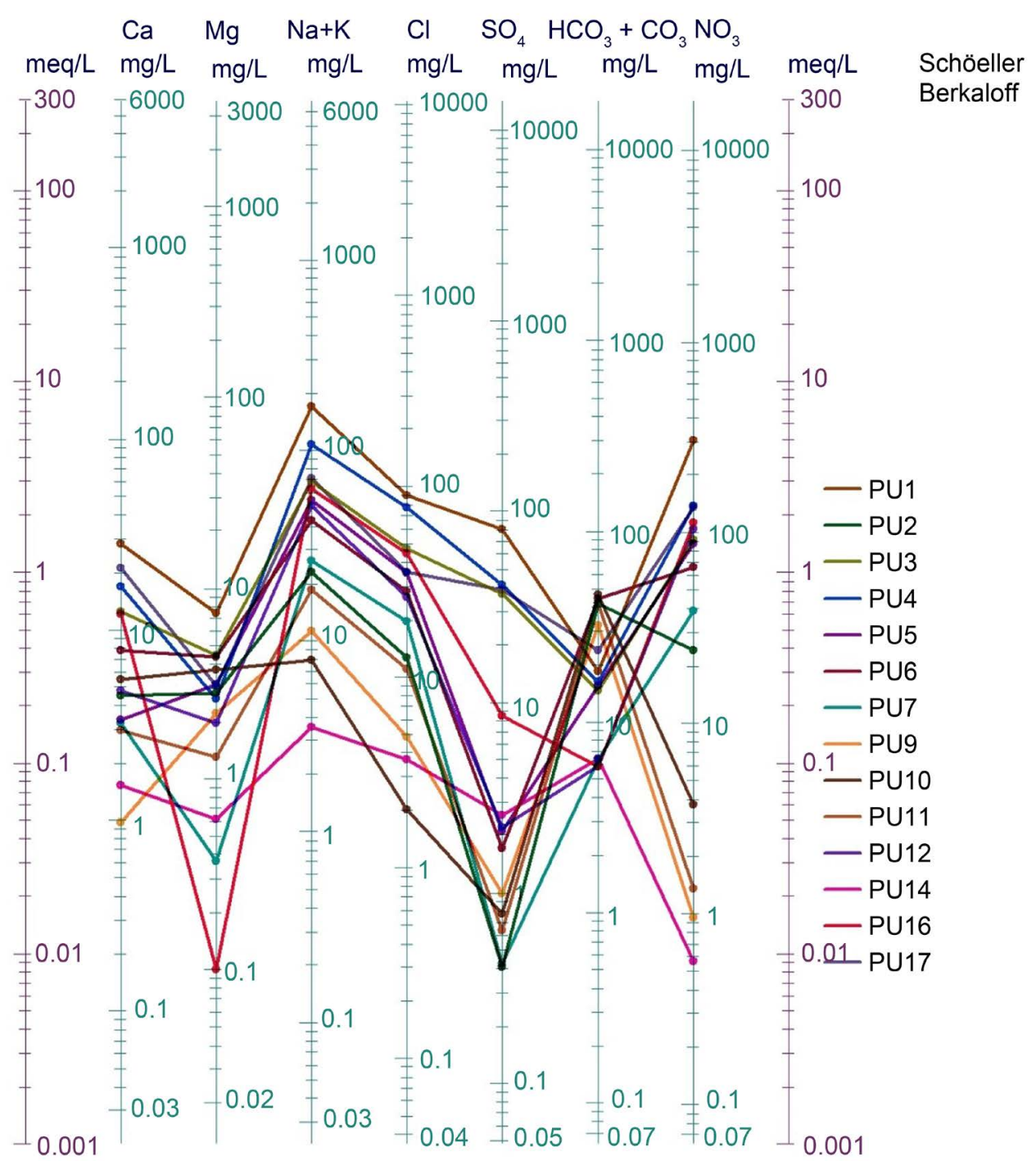

Figure 5. Schöeller-Berkaloff diagram.

$\mathrm{Na}^{+} / \mathrm{Cl}^{-}, \mathrm{Na}^{+} / \mathrm{K}^{+}, \mathrm{Ca}^{2+} / \mathrm{Mg}^{2+}, \mathrm{SO}_{4}^{2-} / \mathrm{Cl}^{-} \ldots$ These reports can also be represented in the form of graphs of an element compared to the other.

The hydrochimy of the free groundwater is also characterized by various ionic reports (Table 3). The $\mathrm{Ca} / \mathrm{Mg}$ report is characteristic of the course of groundwaters, variable between 0.27 and 73.54 (Figure $8(\mathrm{a})$ ). The strongest values are observed in water of well PU16.This could be explained by a more important time of residence at the level of this well.

The report $\mathrm{Cl} / \mathrm{Na}$ (Figure $8(\mathrm{~b})$ ) lies between 0.22 and 1.04. If sodium would come from the dissolution of halite, this report should be equal to 1 . However it is lower at 1 in $90.90 \%$ of the water samples, which indicates that the primary source of sodiumcomes from salts such as the halite or sulphate of sodium, nor of potassium chloride or potassium sulphate. 


\section{Unconfined AQ1}
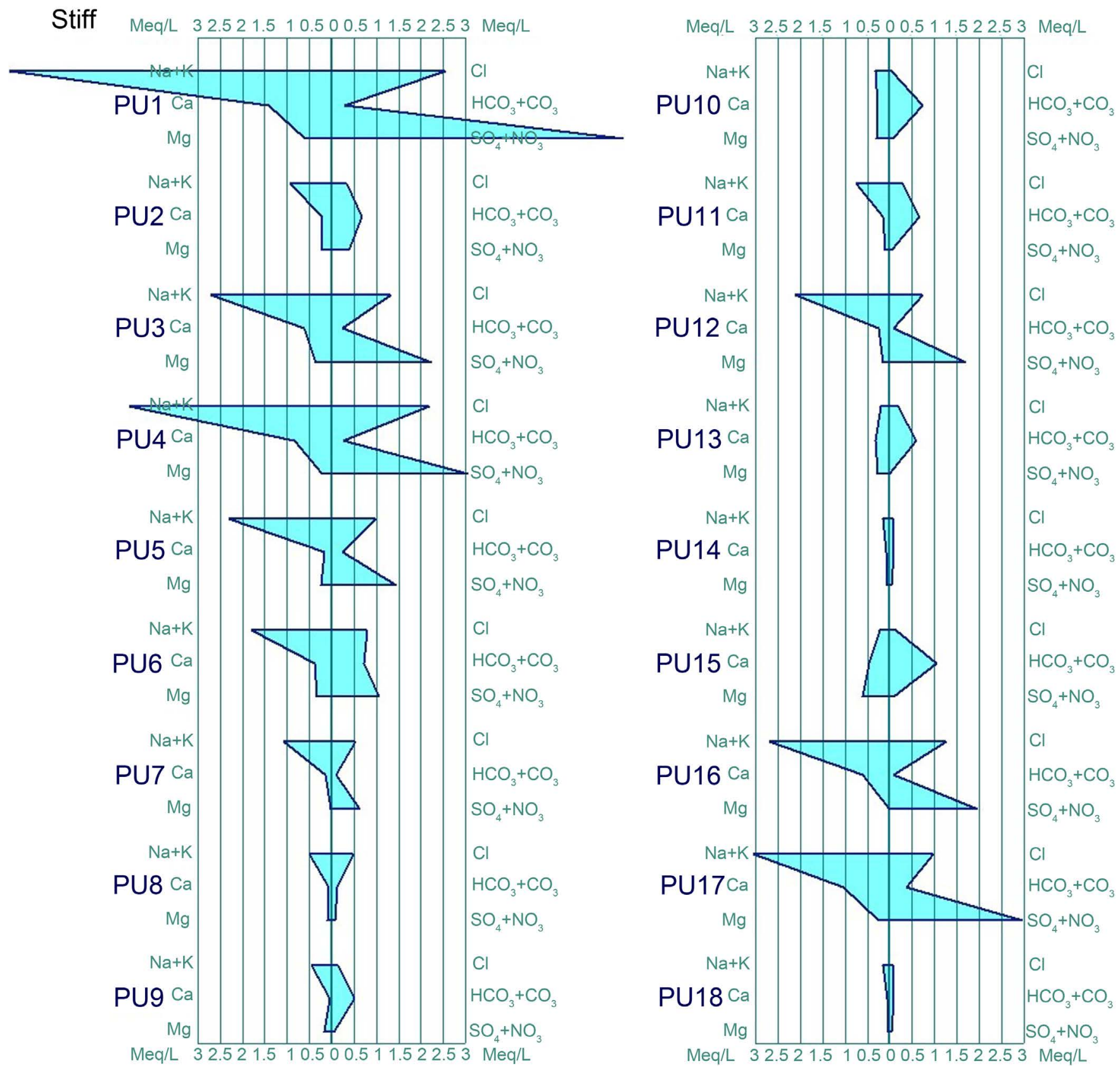

Figure 6. Stiff diagram.

\section{Conclusion}

The study of the hydrochemical characteristics of undergroundwaters of the unconfined water of the area of Pointe-Noire was carried out starting from the combination of the hydrogeological, hydrochemical methods, and of the classical statistical analysis. This study highlights the various physicochemical characteristics of water of the site. The study raises that the undergroundwaters are in extreme cases of an intrusion salt- 


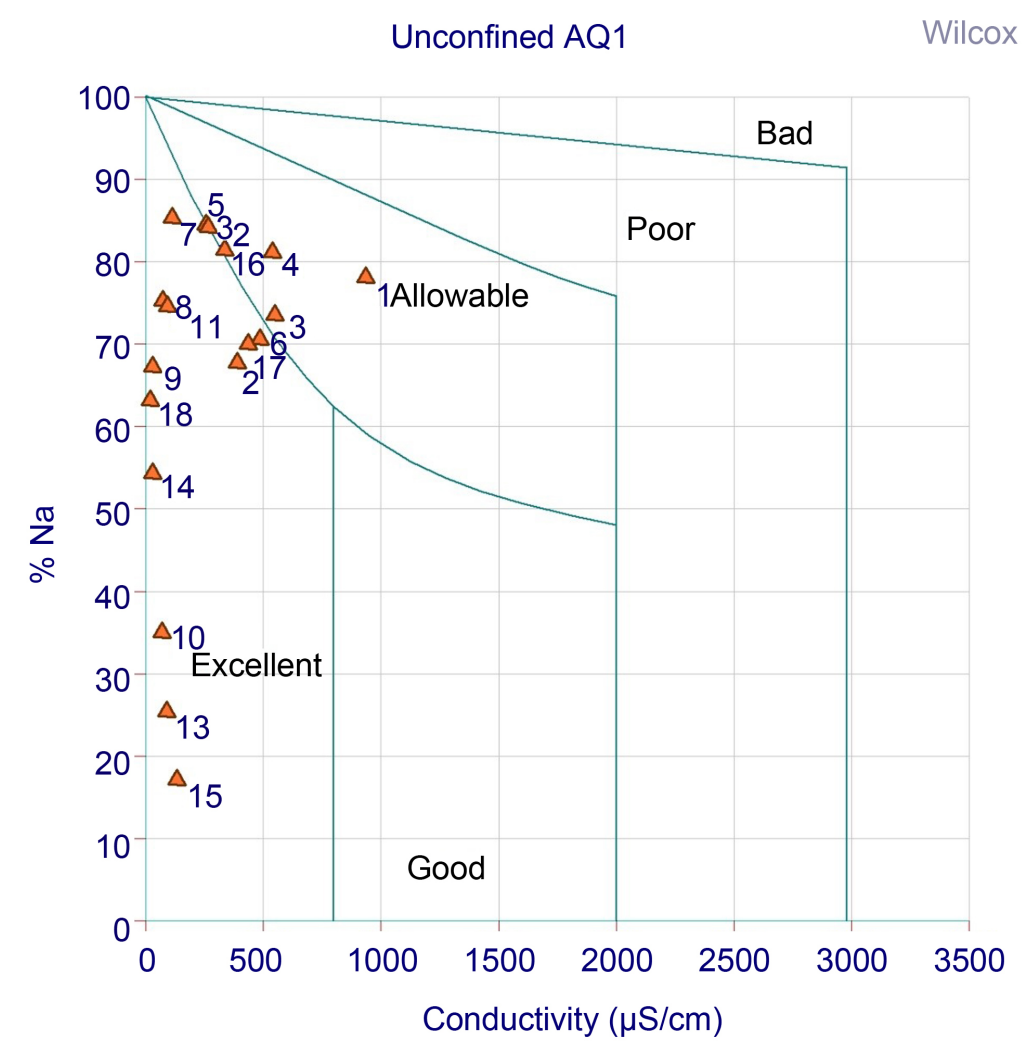

Figure 7. Wilcox diagram.

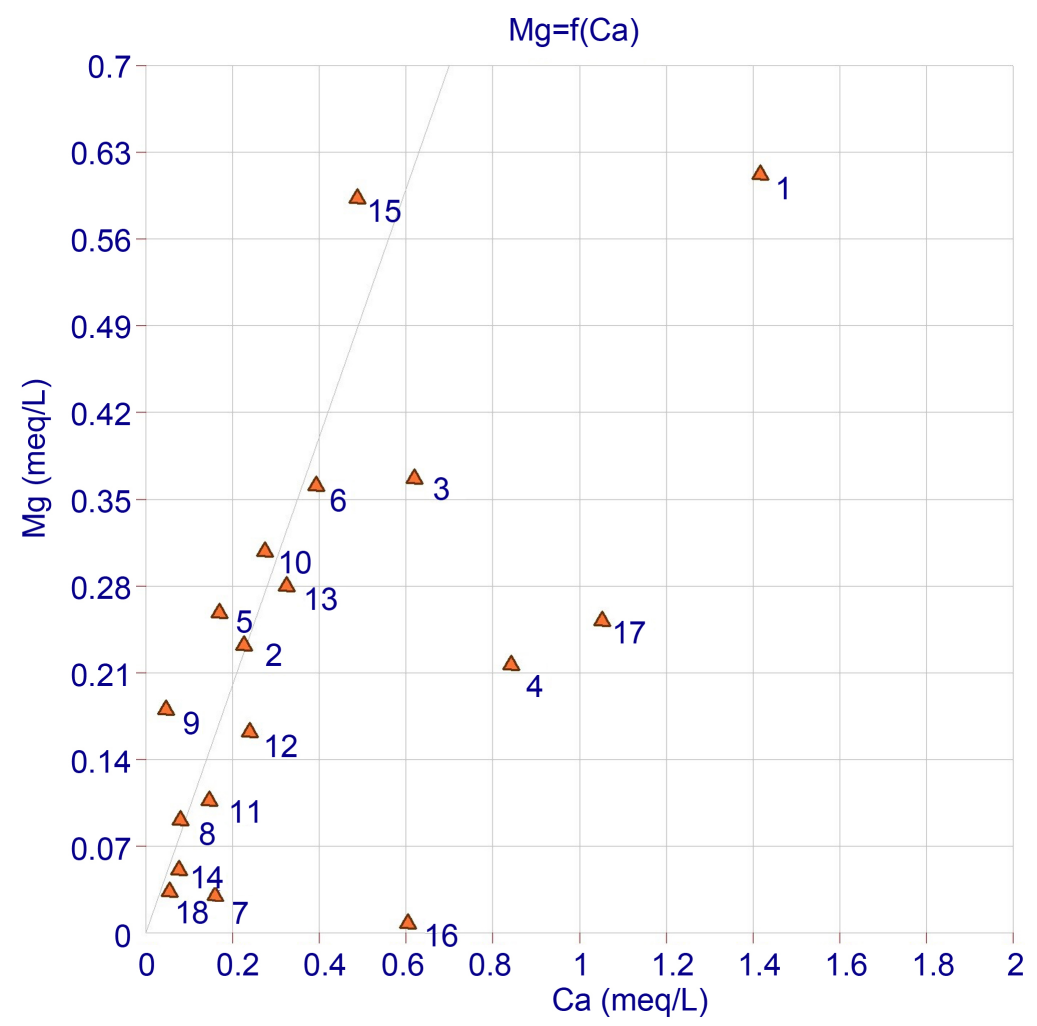

(a) 


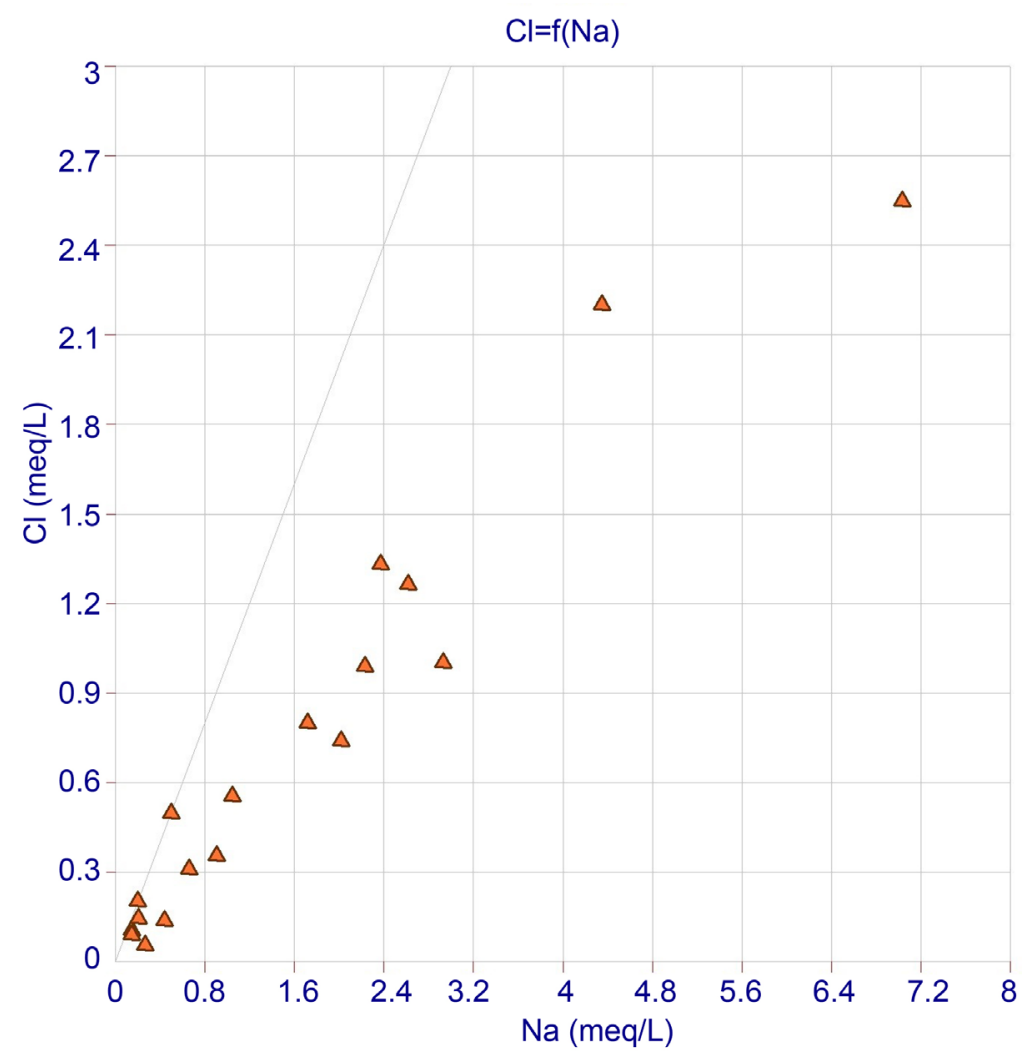

(b)

Figure 8. (a) Report $\mathrm{Ca} / \mathrm{Mg}$; (b) Report $\mathrm{Cl} / \mathrm{Na}$.

Table 3. Ionic reports and chemical facies of the samples of waters.

\begin{tabular}{|c|c|c|c|c|c|c|c|c|c|}
\hline Denominated & Location of zones & {$[\mathrm{Cl}-(\mathrm{Na}+\mathrm{K})] / \mathrm{Cl}$} & $\mathrm{Mg} / \mathrm{Ca}$ & $\mathrm{Ca} / \mathrm{Mg}$ & $\mathrm{Na} / \mathrm{K}$ & $\mathrm{Ca}+\mathrm{Mg}$ & $\mathrm{Na}+\mathrm{K}$ & $\mathrm{Cl} / \mathrm{Na}$ & Chemical facies \\
\hline PU1 & MPAKA & -1.836 & 0.432 & 2.315 & 35.33 & 2.028 & 7.224 & 0.363 & Chlorinated sodic and potassic \\
\hline PU2 & BISONGO & -1.686 & 1.024 & 0.977 & 16.22 & 0.458 & 0.961 & 0.395 & Bicarbonated sodic and potassic \\
\hline PU4 & MBOTA COMAPONT & -1.062 & 0.257 & 3.894 & 22.72 & 1.058 & 4.539 & 0.506 & Chlorinated sodic and potassic \\
\hline PU5 & TCHIBATI & -1.338 & 1.527 & 0.655 & 24.83 & 0.427 & 2.318 & 0.445 & Chlorinated sodic and potassic \\
\hline PU7 & $\mathrm{Km}^{8}$ & -0.994 & 0.187 & 5.341 & 17.92 & 0.191 & 1.109 & 0.529 & Chlorinated sodic and potassic \\
\hline PU8 & Amour du pays & -0.037 & 1.157 & 0.864 & 33.77 & 0.17 & 0.519 & 0.993 & Chlorinated sodic and potassic \\
\hline PU9 & Hopital Loandjili & -2.401 & 3.707 & 0.27 & 16.92 & 0.229 & 0.47 & 0.311 & Bicarbonated sodic and potassic \\
\hline PU10 & Aeroport AA Neto & -4.475 & 1.123 & 0.891 & 5.651 & 0.582 & 0.314 & 0.215 & Bicarbonated calcic and magnesian \\
\hline PU11 & Quartier Loussala & -1.407 & 0.719 & 1.391 & 7.32 & 0.255 & 0.746 & 0.472 & Bicarbonated sodic and potassic \\
\hline PU14 & Kouikou & -0.445 & 0.663 & 1.508 & 31.23 & 0.127 & 0.151 & 0.714 & Chlorinated sodic and potassium \\
\hline PU15 & $\mathrm{Km}^{4}$ & -0.53 & 1.216 & 0.823 & 12.16 & 1.08 & 0.224 & 0.707 & Bicarbonated calcic and magnesian \\
\hline PU16 & TiéTié & -1.129 & 0.014 & 73.54 & 37,92 & 0.613 & 2.688 & 0.482 & Chlorinated sodic and potassic \\
\hline PU17 & Voungou & -2.038 & 0.24 & 4.172 & 25.43 & 1.305 & 3.042 & 0.342 & Chlorinated sodic and potassic \\
\hline PU18 & Mongo Mpoukou & -0.661 & 0.609 & 1.643 & 25.79 & 0.088 & 0.151 & 0.625 & Chlorinated sodic and potassic \\
\hline
\end{tabular}


works, because the limits of the diagram of Wilcox show an excellent water in the majority of the wells which tend towards the limit of admissibility. This hydrochemical study made it possible to highlight the prevalence of sodic and potassic facies chlorinated in groundwaters of the AQ1 unconfined water in the area of Pointe-Noire. In this area, the groundwaters of the unconfined water gather in three principal-hydro facies: Potassic and sodic chlorinated water is the most important (66.7\%) studied water; calcic and magnesian bicarbonated water (16.65\%) and the potassic and sodic bicarbonate ones (16.65\%).

\section{References}

[1] N’Kaya, M. (2012) Etude hydrogéologique, hydrochimique in situ et modélisation hydrodynamique du système aquifère du bassin sédimentaire côtier de la région de Pointe-Noire. Thèse de doctorat unique.

[2] IWACO (1982) Amélioration de l'alimentation en eau potable de Pointe Noire. Etude préliminaire. Rapport Technique No. 239/SNDE.

[3] SAFEGE (1990) Ville de Pointe Noire-Alimentation en eau-Rehabilitation des foragesEtude de nappe. Rapport de synthèse AO/FD/T206-SNDE.

[4] Moukolo, N. (1984) Ressources en eau souterraine et approvisionnement-Essai d'analyse socio-économique en région équatoriale humide (régions de Brazzaville et Pointe-Noire, Congo). Thèse de doctorat 3 e cycle en géologie appliquée, Université des sciences et techniques du Lanquedoc.

[5] Moukolo, N. (1992) Etat de connaissances actuelles sur l'hydrogéologie du Congo Brazzaville. Hydrogéologie, 1-2, 47-58.

[6] Foster, S.S.D. (1995) Groundwater for Development-An Overview of Quality Constraints. In: Nash, H. and Mc Call, G.J.H., Eds., Groundwater Quality, 17 ${ }^{\text {th }}$ Special Report, Chapman and Hall, London, 1-3.

[7] Mor, S., Ravindra, K., Dahiya, R.P. and Chandra, A. (2006) Leachate Characterization and Assessment of Groundwater Pollution Near Municipal Solid Waste Landfill Site. Environmental Monitoring and Assessment, 118, 435-456 [224]. http://dx.doi.org/10.1007/s10661-006-1505-7

[8] Yermani, M., Zouari, K., Michelot, J.L., Mamou, A. and Moumni, L. (2003) Approche géochimique du fonctionnement de la nappe profonde de Gafsa Nord (Tunisie centrale). Journal des Sciences Hydrologiques, 48, 95-108. http://dx.doi.org/10.1623/hysj.48.1.95.43482

[9] Alayat, H. and Lamouroux, C. (2007) Caractérisation physico-chimique des eaux thermominérales des monts de la Cheffia (extrême Nord-Est algérien). La Presse thermale et climatique, 144, 191-199.

[10] Tathy, C., Matini, L., Mabiala, B., Antoine, F. and Moukandi N'Kaya, G.D. (2010) Hydrochemistry of Groundwater in the Aquifer AQ-2 in Pointe-Noire, South-West Congo-Brazzaville. Research Journal of Applied Sciences, 5, 361-369.

http://dx.doi.org/10.3923/rjasci.2010.361.369

[11] Kouassi, A.M., Yao, K.A., Ahoussi, K.E., Seki, C.L., Yao, N.A. and Kouassi, K.I. (2010) Apports des méthodes statistiques et hydrochimiques à la caractérisation des eaux des aquifères fissurés de la région du N’zi-Comoé (Centre-Est de la Côte d'Ivoire). International Journal of Biological and Chemical Sciences, 4, 1816-1838.

[12] Ahoussi, K.E., Oga, Y.M.S., Koffi, Y.B., Kouassi, A.M., Soro, N. and Biemi, J. (2011) Caractérisation hydrogéochimique et microbiologique des ressources en eau du site d'un Cen- 
tre d'Enfouissement Technique (CET) de Côte d'Ivoire: Cas du CET de Kossihouen dans le District d'Abidjan (Côte d'Ivoire). International Journal of Biological and Chemical Sciences, 5, 2114-2132. http://dx.doi.org/10.4314/ijbcs.v5i5.32

[13] Ahoussi, M.A., Koffi, E.K., Ak, B.Y. and Biemi, J. (2012) Caractérisation hydrogéochimique des eaux des aquifères fissurés de la zone Guiglo-Duekoué (Ouest de la Côte d'Ivoire). International Journal of Biological and Chemical Sciences, 6, 504-518.

[14] Ahoussi, K.E., Koffi, Y.B., Kouassi, A.M., Soro, G. and Biemi, J. (2013) Étude hydrochimique et microbiologique des eaux de source de l'ouest montagneux de la Côte d'Ivoire: Cas du village de Mangouin-Yrongouin (Souspréfecture de Biankouman). Journal of Applied Biosciences, 63, 4703-4719. http://dx.doi.org/10.4314/jab.v63i1.87245

[15] Eblin, S.G., Sombo, A.P., Soro, G., Aka, N., Kambiré, O. and Soro, N. (2014) Hydrochimie des eaux de surface de la région d'Adiaké (sud-est côtier de la Côte d'Ivoire). Journal of Applied Biosciences, 75, 6259- 6271. http://dx.doi.org/10.4314/jab.v75i1.10

[16] CDC-EPA (1999) Health Effects from Exposure to High Levels of Sulfate in Drinking Water Study. EPA 815-R-99-001, January.

[17] Aghzar, N., Bellouti, H. and Soudi, B. (2001) Pollution nitrique des eaux souterraines au Tadla (Maroc). Revue des Sciences de I Eau, 15, 459-492.

[18] Sinan, M. (2000) Méthodologie d'identification, d'évaluation et de protection des ressources en eau des aquifères régionaux par la combinaison des SIG, de la géophysique et de la géostatistique. Application à l'aquifère du Haouz de Marrakech (Maroc). Thèse d'Etat, Université Mohamed V de Rabat, Maroc.

[19] Simler, R. (2004) Diagrammes. Laboratoire d'Hydrogéologie d'Avignon, Université d'Avignon, logiciel d'hydrochimie multilangage en distribution libre.

[20] Rosenthal, E. (1987) Chemical Composition of Rainfall and Groundwater in Recharge Areas of the Bet Shean-Harold Multiple Aquifer. Journal of Hydrology, 89, 329-352. http://dx.doi.org/10.1016/0022-1694(87)90185-5

[21] Vengosh, A. and Rosenthal, E. (1994) Saline Groundwater in Israel: Its Bearing on the Water Crisis in the Country. Journal of Hydrology, 156, 389-430. http://dx.doi.org/10.1016/0022-1694(94)90087-6

[22] Morell, I., Gimenez, E., Fagundo, R., Pulido-Bosch, A., Lopez-Chicano, M., Calvache, M.L. and Rodriguez-Rubio, J.E. (1997) Hydrochemitry and karstification in the Cienaga de Zapata aquifer (Matanzas, Cuba). In: Karst Water \& Environmental Impacts, Günay \& Jonhsoneds, Balkema, 191-198.

[23] Davis, S.N., Whittemore, D.O. and Fabryka-Martin, J. (1998) Uses of Chloride/Bromide Ratios in Studies of Potable Water. Groundwater, 36, 338-350. http://dx.doi.org/10.1111/j.1745-6584.1998.tb01099.x 
Submit or recommend next manuscript to SCIRP and we will provide best service for you:

Accepting pre-submission inquiries through Email, Facebook, LinkedIn, Twitter, etc. A wide selection of journals (inclusive of 9 subjects, more than 200 journals)

Providing 24-hour high-quality service

User-friendly online submission system

Fair and swift peer-review system

Efficient typesetting and proofreading procedure

Display of the result of downloads and visits, as well as the number of cited articles

Maximum dissemination of your research work

Submit your manuscript at: http://papersubmission.scirp.org/

Or contact gep@scirp.org 